\title{
MALE GENITALIA VARIABILITY IN CRANIOPHORA LIGUSTRI (LEPIDOPTERA: NOCTUIDAE: ACRONICTINAE)
}

\author{
ÁdÁm KIss ${ }^{1}$, János P. Tóth ${ }^{2}$ and Zoltán VARGA ${ }^{1}$ \\ ${ }^{1}$ Department of Evolutionary Zoology and Human Biology, University of Debrecen \\ H-4032 Debrecen, Egyetem tér 1, Hungary \\ E-mails:woodpecker.86@gmail.com,varga.zoltan@science.unideb.hu \\ ${ }^{2} M T A-D E$ 'Lendület' Behavioural Research Group, H-4032 Debrecen, Egyetem tér 1, Hungary; \\ E-mail:acutiformis@yahoo.com
}

Craniophora ligustri is the most widely distributed species within the genus Craniophora. We used geometric morphometry to assess the shape variation of male valvae in the Western Palaearctic and Russian Far East populations of C. ligustri including the subspecies C. $l$. carbolucana and C. l. hyrcanica. Outlines were transformed using Hangle Fourier method followed by shape analyses using multivariate statistics (CVA, UPGMA). Based on the results the Far Eastern sample is clearly separated from the Western Palaearctic populations. The West Palaearctic samples were split to two demes, a Northern and a Southern one. The probable refugia of the Southern deme may have extended from South Italy, the Balkan Peninsula across the Euxinic coast of Asia Minor to the Talysh and Northern Iran (Hyrcanian part of Elburs Mts), while the refugia of the Northern deme have been supposedly extra-Mediterranean.

Keywords: geographical differentiation, Noctuidae, multivariate statistics.

\section{INTRODUCTION}

Lepidoptera is one of the largest orders of insects with approximately more than 150 thousand species described (NieuKerken et al. 2011). The first lepidopterans have already appeared in the Late Triassic and most of the main lineages have evolved during the Upper Cretaceous, following the radiation of the flowering plants (Grimaldi \& Engel 2005, Wahlberg et al. 2013). Noctuidae is commonly regarded as one of the largest lepidopteran family (Fibiger \& Lafontaine 2005, Mitchell et al. 2006, Zahiri et al. 2011) with more than 11.000 described taxa (Nieukerken et al. 2011). Such a high number is resulted from the immense radiation of higher Ditrysian clades as a consequence of the diversification of the vegetation mostly in the Upper Tertiary (Grimaldi \& Engel 2005, Wahlberg et al. 2013). Acronictinae, one of the phylogenetically younger subfamilies, belongs to 'trifid noctuids' (FIBIGER \& LAFONTAINE 2005). 
This subfamily can be divided into two main branches according to the external morphology and genital characters (Fibiger et al. 2009). The first clade includes the genus Acronicta Ochsenheimer, 1816 and related taxa (e.g. Moma, Oxycesta, Simyra) with approximately more than 200 described species. In this clade, an additional subclade can be distinguished, the genus Cranionycta de Lattin, 1949 which shows intermediate traits between Acronicta and Craniophora (de Lattin 1949, Inoue \& Sugi 1958, Kononenko et al. 1998). The other clade includes the genus Craniophora Snellen, 1867 with less than 30 described species (Hampson 1909, Kozhantshikov 1950, Holloway 1989, Poole 1989, Han \& Kononenko 2010). The identification of a Craniophora species is difficult, especially in the main species-groups (fasciata-, harmandi- and pontica-group) due to the high similarity of external characters (Kiss \& GyulaI 2013). The species of this genus mainly occur in the Eastern Palaearctic, IndoMalaysian and Australian Regions, with only a few species known from the Afrotropical Region (Poole 1989, Fibiger et al. 2009).

The type species of the genus, Craniophora ligustri ([Denis \& Schiffermüller], 1775) is a polytypic, European-East Asiatic species with disjunct range. It occurs across Europe except for Iceland, Malta, northern Fennoscandia and the eastern part of European Russia (eastward from the Saint PetersburgKazan-Volgograd line, Kozhantshiкоv 1950, Matov pers. comm.). Outside Europe, the species is found in Turkey, Israel, Caucasus and Transcaucasia, North Iran, Turkmenistan, Russian Far East, Central and Eastern China, Korea, and Japan (Draudt 1937, 1950, Kozhantshikov 1950, Ebert \& Hacker 2002, Kononenko 2005, Kravchenko et al. 2006, Fibiger et al. 2009). Larvae feed on the leaves of various species of Oleaceae, mainly Fraxinus, Ligustrum, Syringa, but - according to some references - occasionally also on some Aceraceae, Betulaceae, Corylaceae, Elaeagnaceae and Viburnaceae (Fibiger et al. 2009, Kononenko 2010).

The descriptions of the three subspecies from the Western Palaearctic are based on wing patterns and colouration. The nominotypical subspecies C. $l$. ligustri is described from Austria, Vienna region. Since the type specimen has been destroyed (Poole 1989), reference can only be provided for the specimens of the NHMW from this region (figured e.g. in LöDL et al. 2012, pp. 2627). C. l. carbolucana Hartig, 1968 (from South Italy, Mt. Vulture), according to the original description, mostly differs from the nominotypical subspecies by its constantly deep blackish colouration of the forewings with finely whitish defined orbicular and only externally lighter marked reniform maculae, with dark fuscous hindwings and underside of wings. The C. l. hyrcanica Hacker \& Ebert, 2002 (from North Iran, Mt. Elburs) is characterised by its average smaller size, from greyish to dark greyish ground colour with some ochreous shading and less contrasting colouration of the medial field of forewings. 
However, these external differences should not be overestimated since it is known that external morphology, especially wing colouration and body size could be influenced by environmental factors (SHAPIro 1974, CESARONi et al. 1994, Roskam \& Brakefield 1999, Dapporto 2008, Tóth \& Varga 2011, SANZANA et al. 2013, Mega 2014).

Generally, the genital characters are known more stable and informative in taxonomic aspect than the wing patterns (Shapiro \& Porter 1989, Mutanen 2005, Dapporto 2008, Tóth \& Varga 2010, 2011). During the past half of the century, morphometrics has become a widely used method in taxonomy, with a special respect to geometric morphometrics (RoHLF \& MARCus 1993, Adams et al. 2004, Zelditch et al. 2004, Mutanen et al. 2007, Dapporto 2008, 2010, То́тн et al. 2014). Geometric morphometrics proved to be suitable to uncover and quantify small intra- or interspecific differences (e.g. GARNIER et al. 2005, DAPporto 2008, Tóth \& VARGa 2011).

Unfortunately, the variability of the genitalia of C. ligustri is poorly known. Although the description of the genitalia of $C$. ligustri is detailed by Fibiger et al. (2009), however, the figured vesica and valvae do not belong to the same specimen. The vesica belongs to the type specimen of C. ligustri gigantea Draudt, 1937. Hartig (1968) described C. l. carbolucana based on wing pattern without considering genitalia characters. EBERT and HACKer (2002) also described C. l. hyrcanica based on wing pattern elements. However, they have figured the genitalia of the type specimen. To our knowledge, detailed analysis on the genitalia of $C$. ligustri has not been carried out yet.

The aim of this paper is to survey the shape variation of the male valvae by geometric morphometric method in the Western Palaearctic and Russian Far East populations of C. ligustri including subspecies C. l. carbolucana and C. l. hyrcanica, to reveal the possible geographical pattern. We also give some biogeographical interpretation of our findings.

\section{MATERIAL AND METHODS}

In this survey, 206 male specimens of $C$. ligustri were examined to reveal the possible geographical differences among the Western Palaearctic populations.

Specimens, based on the collecting sites, were classified as follows: South England (Eng, $\mathrm{N}=14$ ), Denmark (Den, $\mathrm{N}=15$ ), Finland (Fin, $\mathrm{N}=15)$, North Alps (AlpN, $\mathrm{N}=14$ ), South Alps (AlpS, $N=15)$, Spain (Spa, $N=13$ ), South Italy (Italy, $N=16$ ), Croatia (Cro, $N$ $=16$ ), Bulgaria (Bulg, $N=20$ ), Hungary (Hun, $N=14$ ), Ukraine (Ukr, $N=13$ ), Caucasus (Cauc, $\mathrm{N}=14$ ), North Iran (Iran, $\mathrm{N}=14$ ), Russian Far East (RussE, $\mathrm{N}=13$ ). To estimate the level of inter-specific variability of the valvae we used Craniophora pontica (pont, $\mathrm{N}=14$ ) as outgroup.

A representative sample of the South Italian and North Iranian populations was collected from the type localities and nearby territories of the subspecies carbolucana and hyr- 
canica. The North Iranian sample included also one of the paratypes of hyrcanica from the Talysh Mts.

The examined specimens belong to the following collections: Hungarian Natural History Museum, Budapest, Hungary (HNHM), Museo Civico di Storia Naturale 'Giacomo Doria', Genoa, Italy (MSMG), Museo di Storia Naturale di Milano, Italy (MSNM), Museo Nacional de Ciencias Naturales, Madrid, Spain (MNCN), Natur-Museum Luzern, Switzerland (NML), Naturhistorisches Museum Wien, Austria (NHMW), Zoological Collection of the University of Debrecen, Hungary (UD, coll. Z. Varga deposited here), Zoological Museum, University of Copenhagen, Denmark (ZMUC), Zoological Museum, University of Oulu, Finland (ZMUO), Zoologische Staatssammlung München, Germany (ZSM), Zoologisches Forschungsmuseum Alexander Koenig, Bonn, Germany (ZFMK), E. Derzhinskij (Vitebsk, Belarus), P. Gyulai (Miskolc, Hungary), G. Ronkay (Budapest, Hungary), Sz. Szanyi (Velyka Dobron, Ukraine), J. L. Yela (Toledo, Spain) and the private collection of the first author.

Genitals were dissected following mainly the techniques recommended by RoBinson (1976) with minor modifications adapted to larger noctuid moths. A $15 \%$ potassium hydroxide $(\mathrm{KOH})$ solution was used to macerate the full abdomen. Eosin dye was used to stain the weakly sclerotized structures. After dehydrating in $96 \%$ ethanol, the genital apparatus was mounted to Euparal. Photos of the slides were taken by an Olympus DP 70 digital microscope camera connected to an Olympus SZX12 zoom stereo microscope.

The outlines of the left valvae (Fig. 1) were digitalised by tpsDig 2.16 (RohlF 2010). PAST 2.17c (HAMmer et al. 2001) software package was used to calculate Hangle Fourier harmonics. Fourier shape analysis use digitalised xy-coordinates from the outline of the given shape to reconstruct the outline using harmonically related trigonometric curves. The produced Fourier coefficients, two per harmonic, describe the size ('amplitude') and

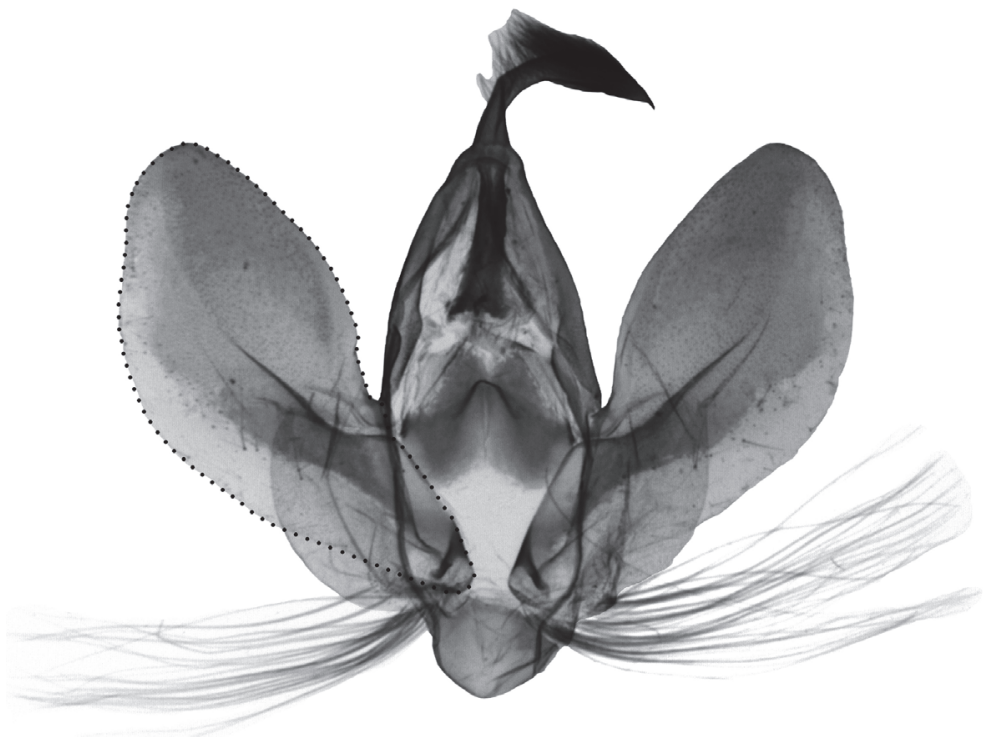

Fig. 1. Genital capsule of Craniophora ligustri with the 100 semi landmarks (black dots) of left valvae 
angular offset relative to the starting position ('phase angle') of each harmonic curve. In this way, and using some appropriate number of harmonics, it is possible to describe even extremely complex shapes (for more detail see: Haines \& CRAMpton 2000). The first 11 harmonics capture more than $96 \%$ of the total integrated power of the shape. Fourier coefficients were analysed by CVA using the MASS package. Wilks' $\lambda$ was used to measure the discriminatory power of the CVA model with values ranging from 0 (perfect discrimination) to 1 (no discrimination). To test the statistical significance of the visible pattern obtained by CVA plot and UPGMA trees, MANOVA (Multivariate Analysis of Variance) was used. We also interested the classification success of the main groups, thus Jackknife classification was carried out using PAST. In this test one known specimen is sequentially omitted at a time, and assigned using the discriminant function the calculation of which is based on all cases except that particular individual. The number of correct assignments was used to evaluate the predictive power of the discriminant function of CVA.

Cluster analysis was applied using the 'pvclust' package of the R 3.0.3 computing environment (R Core Team 2014). P-values (\%) for Hierarchical Clustering were computed via multiscale bootstrap resampling (Suzuki \& Shimodaira 2011). The UPGMA tree was built using Mahalanobis distances. The 'pvclust' package provides two types of $p$-values: AU (Approximately Unbiased) $p$-value and BP (Bootstrap Probability) value. AU $p$-value, which is computed by multiscale bootstrap resampling, is a better approximation to unbiased $p$-value than BP value computed by normal bootstrap resampling. The number of bootstrap replications was set to 10.000 . To visualise the morphological variability of the genitalia in geographical space, the first CV axis was interpolated using Inverse Distance Weighting (IDW) method in Quantum GIS 2.0.1 (QGIS Development Team 2014).

Measurement error (ME) was computed by using one-way ANOVA (BAILEY \& BYRNES 1990, GARNIER et al. 2005). All individuals were measured twice and the percentage of ME was defined for each shape variable, independently. The ME values were less than $20 \%$ in all cases, $10 \%$ on average.

\section{RESULTS}

The first 11 harmonics were used as variables in CVA (canonical variate analysis). In the first step, $C$. pontica was set as outgroup. In this case, the first CV axis explained $60.64 \%$ of the variance and the second CV axis $13.69 \%$ of the variance (Wilks' $\lambda=0.004, \mathrm{p}<0.05$ ). When only the groups of $C$. ligustri were tested, the first $\mathrm{CV}$ axis explained $40.91 \%$ of the total variance and the second CV axis $15.2 \%$ of the variance (Wilks' $\lambda=0.02, \mathrm{p}<0.05$ ). The pairwise MANOVA showed that $C$. pontica was significantly different from all other groups. The Russian Far East population was also significantly different from all groups of $C$. ligustri except the North Iranian sample.

The centroids of the C. ligustri groups are illustrated on Figure 2. The most separated group is the Russian Far East, as it was expected based on the significance tests. The rest of the a priori assemblages were combined into a Northern group and a Southern one. The UPGMA tree (Fig. 3) was constructed on hierarchical clustering via multiscale bootstrap resampling based on Mahalanobis distances. It shows a very similar result to the CVA plot. C. pontica 


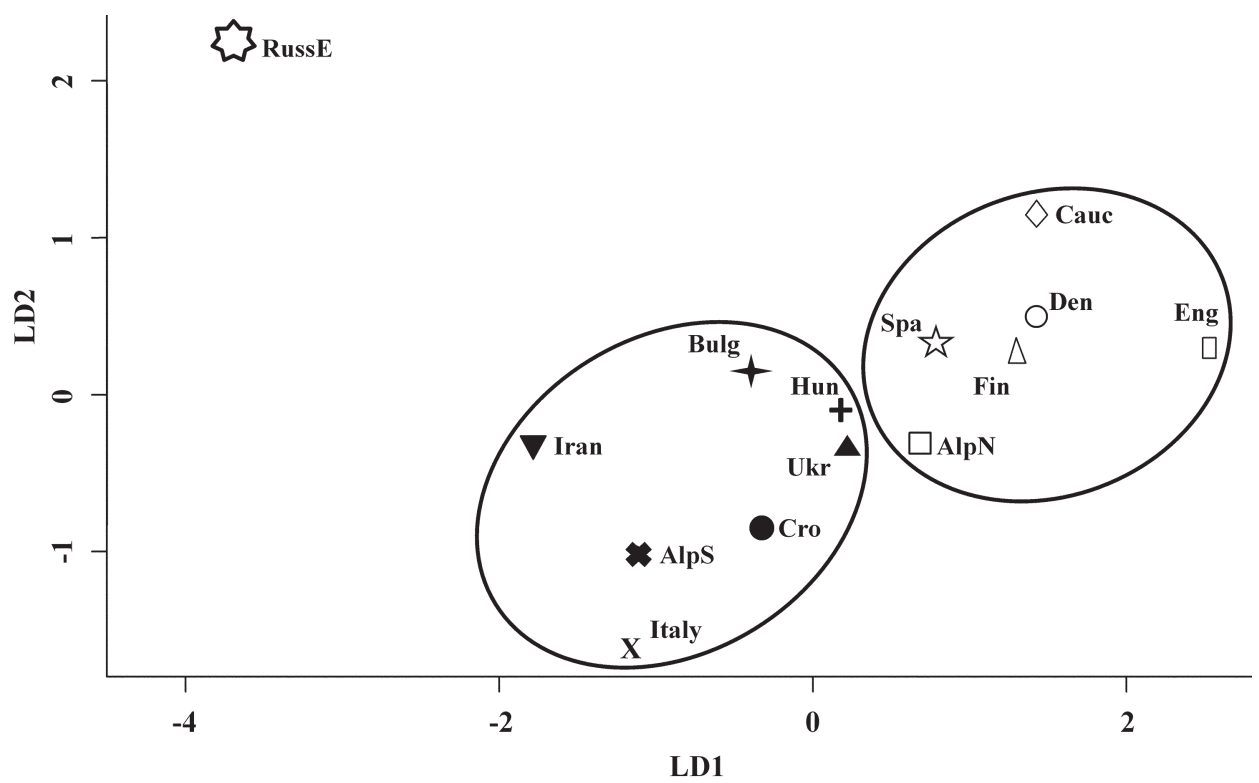

Fig. 2. Scatter plot of the group centroids. The filled symbols mark the Southern group, the empty symbols mark the Northern group. Further explanation of the legends, see 'Material and methods'

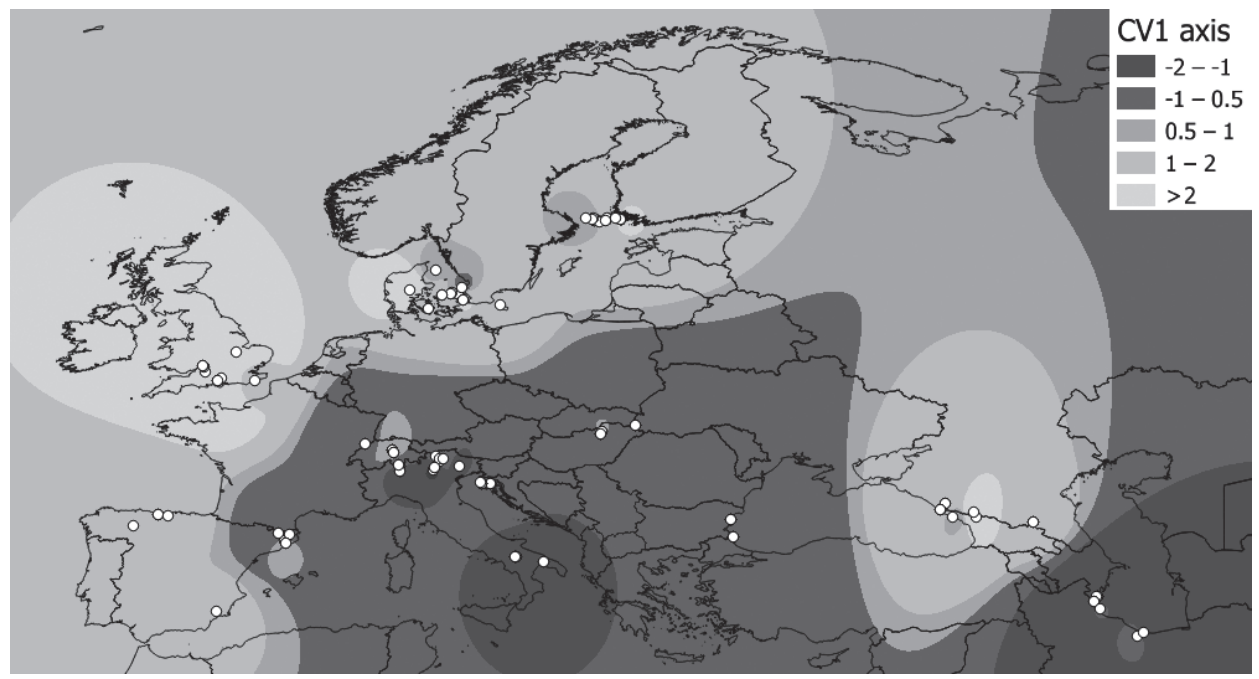

Fig. 4. Inverse distance weighting (IDW) interpolation of the first CV axis. The CV1 axis can explain $40.91 \%$ of the total variance between groups. Two main group are visible on the map: Northern group (brighter grey) and Southern group (darker grey). White dots indicate the collecting sites of the examined specimens 
Table 1. Results of Jackknife grouping. The groups based on the suggestion of centroids and UPGMA tree. Original groups along rows, CVA groups along columns.

\begin{tabular}{lcccc}
\hline & Southern group & Northern group & Russian Far East & Specimens \\
\hline Southern group & $81.7 \%$ & $16.5 \%$ & $1.8 \%$ & 109 \\
Northern group & $13.1 \%$ & $86.9 \%$ & 0 & 84 \\
Russian Far East & $7.7 \%$ & 0 & $92.3 \%$ & 13 \\
Specimens & 101 & 91 & 14 & 206 \\
\hline
\end{tabular}

is clearly separated from C. ligustri and the sample from the Russian Far East is also separated from the remaining groups. The Northern deme of $C$. ligustri includes the English, Danish, Finnish, North Alpine, Spanish and Caucasian samples, while the Southern deme contains the South Alpine, South Italian, Croatian, Bulgarian, Hungarian, Ukrainian and North Iranian samples.

The CVA plot and the UPGMA tree support the three main branches (i.e., the Russian, the Northern and the Southern ones). These groups were set for Jackknife groupings (Table 1). The $84.5 \%$ of the specimens were well classified. $13.1 \%$ of the specimens of the Northern deme and $16.5 \%$ of the specimens of the Southern deme were overlapping. Only one specimen from the Russian Far East group was misclassified (7.7\%) to the Southern deme and only two specimens from the Southern deme (1.8\%) to the Russian Far East group are misidentified.

To visualise the morphological variability of the genitalia in geographic space, the first $\mathrm{CV}$ axis was interpolated using Inverse Distance Weighting (IDW) method (Fig. 4). The result of the interpolation also suggests that the Western Palaearctic populations of C. ligustri are forming two main clades.

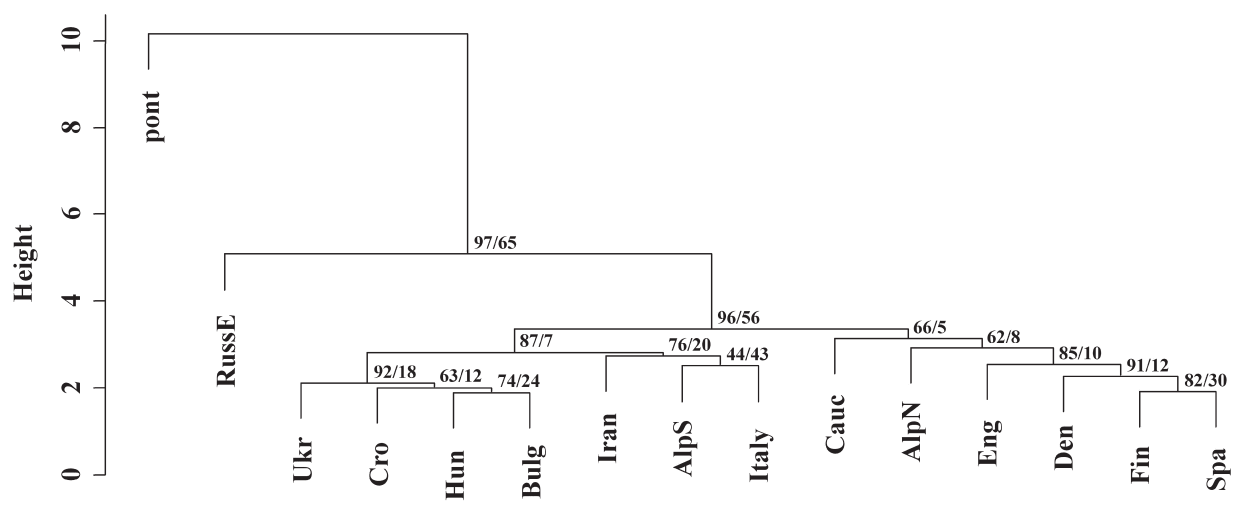

Fig. 3. UPGMA tree based on Mahalanobis distances with AU/BP $p$-value (\%). Further explanation of the legends see 'Material and methods' 


\section{DISCUSSION}

Our findings show that geometric morphometrics based on the outline of valvae proved to be suitable to separate Craniophora pontica from C. ligust$r i$, and also distinguished some different geographical population groups in C. ligustri. However, these differences are rather small due to the simplified shape of the valvae. The value of the Wilks' $\lambda$ is larger by one order of magnitude than for $C$. pontica, indicating that this is a clearly separated species. Within C. ligustri, only populations of the Russian Far East could have been separated from the Western Palaearctic population groups (Fig. 1 \& Table 1). This difference seems to coincide with their disjunct distribution. There are numerous comparable examples in which temperate nemoral species with disjunct distributions show subspecific differentiation (e.g. Stauropus fagi fagi-S. fagi persimilis, Apamea aquila aquila - A. a. discrepans - A. a. substriata, Brachionycha nubeculosa nubeculosa - B. n. kullbergi - B. n. jezoensis, Orthosia gothica gothica-O.g. jezoensis) or they are split to vicariant sister-species (e.g. Spatalia argentina - S. doerriesi, Harpya milhauseri - H. umbrosa, Dicranura ulmi - D. tsvetajevi, Drymonia dodonaea - D. dodonides, Catocala sponsa-C. dula, Jodia croceago - J. sericea) (Schintlmeister 1989, Ronkay et al. 2001, Schintlmeister \& FANG 2001, Goater et al. 2003, Zilli et al. 2009, Ronkay et al. 2011). Most of the examined species in the Russian Far East have paler greyish hindwings suffused with lighter fuscous or greyish scales. It seems that the Russian Far Eastern populations constitute a distinct subspecies. However, it is necessary to compare with other populations from Japan, Korean Peninsula and China, especially with C. l. gigantea Draudt, 1937 (white hindwings with blackish marginal band).

Our results suggest that the Western Palaearctic populations of $C$. ligustri can be subdivided into two (a Northern and a Southern) main population groups (see Results and Figs $2 \& 4$ ). The transitional zone between these demes is likely broad and continuous. This pattern is clearly expressed on the Figure 4.

The grouping of samples on the UPGMA tree (Fig. 3) does not correspond exactly to their actual geographic distribution with incongruencies in relation to the IDW map (Fig. 4), see e.g. the Spanish sample. The IDW strongly suggests the duality of the Spanish individuals but the low number of the samples (six-six specimens in each 'subgroup') did not allow their separation in the cluster analysis. Thus, we have to conclude that the IDW provide more information than the UPGMA tree.

The major refugia of temperate nemoral species were in the Mediterranean peninsulas of Iberia, southern Italy and Balkans during the last glaciation (e.g. Hewitt 1996, 1999, 2004, TABerlet et al. 1998, Sсhмitт 2007). Thus 
the most probable, relatively large refugia of the Southern strain may have extended from South Italy and the Balkan Peninsula across the Euxinic coast of Asia Minor to the Talysh and North Iran (Hyrcanian part of Elburs Mts) from which this strain may have populated south-eastern Central Europe and Southeast Europe, east of the Carpathians as well as, Transcaucasia and North Iran. It seems that the population extending from the South Italian refuge could not leave the peninsula because of the barrier effect of the Alps (BiLton et al. 1998, TABERLET et al. 1998) but obviously populated the southern Alps since the North Italian (South Alps sample) and South Italian (subspecies carbolucana) populations were shown to be identical.

According to the original description, C. l. carbolucana differs from C. l. ligustri externally by its deep blackish ground colour of the forewings (HARTIG 1968) although this form often appears also in northern Italy and Balkans samples, and sometimes even in the samples of the Northern groups. C. l. carbolucana (South Alps and South Italian samples) externally cannot be clearly differentiated from the other European specimens, and its genital trait suggests that this taxon is rather a darker morphotype than a subspecies. It should be re-examined, however, based on larger materials from the Provence region (France) and Sicily (Italy).

Probably several extra-Mediterranean refugia also existed in some parts of southern Central Europe, Southern Urals, Caucasus, Western Asia from which mostly Central and Northern Europe was colonized (STEWART \& Lister 2001, Surget-Groba et al. 2001, Babik et al. 2004, Ursenbacher et al. 2006, Sсhмitt \& Varga 2009, 2012, Stewart et al. 2010, Varga 2010). As the re-colonization might be multidirectional (e.g. Fumagalli et al. 1996, Bilton et al. 1998, Deffontaine et al. 2005, Котцík et al. 2006, Gratton et al. 2008) the Northern strain may have populated Southern Fennoscandia, the British Isles and possibly also the northern Atlantic part of Iberia from an eastern extra-Mediterranean refugial area in the very early postglacial period, before the Littorina transgression. It seems to be more probable that the slight geographical differentiation of these populations can be considered as the consequence of an early postglacial splitting due to post-expansive regression than the signal of several extra-Mediterranean refugia, although the latter possibility cannot be excluded. To explain this pattern we hypothesise that $C$. ligustri has populated the British Isles from Iberia, via the 'Lusitanian' way, similarly to Fraxinus excelsior (Heuertz et al. 2004, Fraxigen 2005), which is probably its most important food plant there. However, no evidence supports the hypothesis that the expansion of $C$. ligustri followed the same track. This question needs a revision using larger sample sizes, since the Iberian specimens from the North Atlantic coast area and from the Eastern Pyrenees seem to belong to different (Northern vs Southern) strains (Fig. 4). 
A few specimens are different from their group average because of the high similarity and simplified shape of the valvae (see the different colour patches on Fig. 4).Unfortunately, our samples are clearly insufficient to decide whether (1) these are individual forms connected to the variation in food plants (distribution of the section Ornus vs Fraxinus, see Wallander 2008, Hinsinger et al. 2013), or (2) the expression of some alleles of the common, ancestral gene pool.

In contrast, C. l. hyrcanica (North Iranian sample) has an average smaller size, and a more uniform ground colour varying from pure greyish to dark greyish with ochreous scales. Although specimens with similar colouration were found also in the Caucasus and the Russian Far East, the medial shadow reaches the inner margin by an angle of about 45 degrees only in the North Iranian sample. These external traits seem to be unique to the population of Talysh and Hyrcanian part of Elburs Mts.

Although our present knowledge about the West Asiatic and Eastern Palaearctic populations (China, Japan, Korean Peninsula) is obviously insufficient to explain completely the distribution of this species, our survey provided, however, useful preliminary information on the matter. A more comprehensive dataset would allow to gain a better understanding of the transitional zone between the two main European demes (Northern and Southern) and to unravel the re-colonization routes of Western Europe (Iberian Peninsula vs Eastern Europe).

Acknowledgements - We would like to thank Zs. Bálint, L. Ronkay (HNHM), M. Tavano (MSMG), F. Rigato (MSNM), M. Paris (MNCN), L. Reser (NML), S. Gaal-Haszler (NHMW), O. Karsholt (ZMUC), M. Mutanen (ZMUO), A. Hausmann (ZSM), D. Stüning (ZFMK), E. Derzhinskij (Vitebsk, Belarus), P. Gyulai (Miskolc, Hungary), G. Ronkay (Budapest, Hungary), Sz. Szanyi (Velyka Dobron, Ukraine), J. L. Yela (Toledo, Spain) for loaning materials, Zs. Bálint (HNHM) for allowing the use of photomicroscope to digitalize the slides, A. Matov (Saint-Petersburg, Russia) for his valuable suggestion and L. Ronkay (HNHM) and Zs. Végvári (Hortobágy National Park Directorate, Debrecen, Hungary) for checking the manuscript.

This research was supported by the OTKA (K-84071) and the European Union and the State of Hungary, co-financed by the European Social Fund in the framework of TÁMOP-4.2.4.A/ 2-11/1-2012-0001 'National Excellence Program'.

\section{REFERENCES}

Adams, D. C., Rohlf, F. J. \& Slice, D. E. (2004): Geometric morphometrics: Ten years of progress following the 'revolution'. Italian Journal of Zoology 71(1): 5-16. https://doi. org/10.1080/11250000409356545 
Babik, W., Branicki, W., Sandera, M., Litvinchuk, S., Borkin, L. J., Irwin, J. T. \& Rafiński, J. (2004): Mitochondrial phylogeography of the moor frog, Rana arvalis. Molecular Ecology 13: 1469-1480. https://doi.org/10.1111/j.1365-294X.2004.02157.x

BAILEY, R. C. \& Byrnes, J. (1990): A new, old method for assessing measurement error in both univariate and multivariate morphometrics studies. Systematic Zoology 39(2): 124-130. https://doi.org/10.2307/2992450

Bilton, D. T., Mirol, P. M., Mascheretti, S., Fredga, K., Zima, J. \& Searle, J. B. (1998): Mediterranean Europe as an area of endemism for small mammals rather than a source for northwards postglacial colonization. Proceedings of the Royal Society B 265: 1219-1226. https://doi.org/10.1098/rspb.1998.0423

Cesaroni, D., Lucarelli, M., Allori, P., Russo, F. \& Sbordoni, V. (1994): Patterns of evolution and multidimensional systematics in graylings (Lepidoptera: Hipparchia). Biological Journal of the Linnean Society 52: 101-119. https://doi.org/10.1111/j.1095-8312.1994. tb00982.x

DApporto, L. (2008): Geometric morphometrics reveal male genitalia differences in the Lasiommata megera/paramegaera complex (Lepidoptera, Nymphalidae) and the lack of a predicted hybridization area in the Tuscan Archipelago. Journal of Zoological Systematics and Evolutionary Research 46(3): 193-288. https://doi.org/10.1111/j.14390469.2007.00453.x

DApporto, L. (2010): Speciation in Mediterranean refugia and post-glacial expansion of Zerynthia polyxena (Lepidoptera, Papilionidae). Journal of Zoological Systematics and Evolutionary Research 48(3): 229-237. https://doi.org/10.1111/j.1439-0469.2009.00550.x

Deffontaine, V., Libois, R., Kotlík, P., Sommer, R., Nieberding, C., Paradis, E., Searle, J. B. \& Michaux, J. R. (2005): Beyond the Mediterranean peninsulas: evidence of Central European glacial refugia for a temperate forest mammal species, the bank vole (Clethrionomys glareolus). Molecular Ecology 14: 1727-1739. https://doi.org/10.1111/ j.1365-294X.2005.02506.x

Draudt, M. (1937): Neue Agrotiden (= Noctuiden)-Arten und Formen aus den Aubeuten von Herrn H. Höne, Shanghai. Entomologische Rundschau 54: 373-376, 381-384, 396-401.

DraudT, M. (1950): Beiträge zur Kenntnis der Agrotiden-Fauna Chinas aus den Ausbeuten Dr. H. Höne's. Mitteilungen der Münchner Entomologischen Gesellschaft 40(1): 1-174.

Ebert, G. \& HAcker, H. H. (2002): Beitrag zur Fauna der Noctuidae des Iran: Verzeichnis der Bestände im Staatlichen Museum für Naturkunde Karlsruhe, taxonomische Bemerkungen und Beschreibung neuer Taxa (Noctuidae, Lepidoptera). Esperiana 9: 237-409.

Fibiger, M. \& Lafontaine, J. D. (2005): A review of the higher classification of the Noctuoidea (Lepidoptera) with special reference to the Holarctic fauna. Esperiana 11: 7-92.

Fibiger, M., Ronkay, L., Steiner, A. \& Zilli, A. (2009): Pantheinae, Dilobinae, Acronictinae, Eustrotiinae, Nolinae, Bagisarinae, Acontiinae, Metoponiinae, Heliothinae and Bryophilinae. Noctuidae Europaeae, Vol. 11. Entomological Press, Sorø, 504 pp.

Fraxigen (2005): Ash species in Europe: biological characteristics and practical guidelines for sustainable use. Oxford Forestry Institute, University of Oxford, Oxford, 128 pp.

Fumagalli, L., Hausser, J., Taberlet, P., Gielly, L. \& Stewart, D. T. (1996): Phylogenetic structure of the Holarctic Sorex araneus group and its relationship with S. samniticus, as inferred from mtDNA sequences. Hereditas 125: 191-199. https://doi.org/10.1111/ j.1601-5223.1996.00191.x

Garnier, S., Magniez-Jannin, F., Rasplus, J-Y. \& Alibert, P. (2005): When morphometry meets genetics: inferring the phylogeography of Carabus solieri using Fourier 
analyses of pronotum and male genitalia. Journal of Evolutionary Biology 18: 269-280. https://doi.org/10.1111/j.1420-9101.2004.00854.x

Goater, B., Ronkay, L. \& Fibiger, M. (2003): Catocalinae \& Plusiinae. Noctuidae Europaeae. Vol. 10. Entomological Press, Sorø, 455 pp.

Gratton, P., Konopiński, M. K. \& Sbordoni, V. (2008): Pleistocene evolutionary history of the Clouded Apollo (Parnassius mnemosyne): genetic signatures of climate cycles and a 'time-dependent' mitochondrial substitution rate. Molecular Ecology 17: 42484262. https://doi.org/10.1111/j.1365-294X.2008.03901.x

Grimaldi, D. \& Engel, M. S. (2005): Evolution of the insects. Cambridge University Press, Cambridge, $755 \mathrm{pp}$.

Haines, J. H. \& Crampton, J. S. (2000): Improvements to the method of Fourier shape analysis as applied in morphometric studies. Palaeontology 43(4): 765-783. https://doi. org/10.1111/1475-4983.00148

Hammer, O., Harper, D. A. T. \& Ryan, P. D. (2001): PAST: Paleontological statistics software package for education and data analysis. Palaeontologia Electronica 4(1): 1-9.

Hampson, G. F. (1909): Catalogue of the Lepidoptera Phalaenae in the British Museum. Vol. 8. British Museum Trustees, Taylor and Francis, London, 583 pp.

Han, H. L. \& KononenKo, V. S. (2010): New species of the genera Acronicta Ochsenheimer, 1816 and Craniophora Snellen, 1867 from China with notes on synonymy and checklist (Lepidoptera, Noctuidae: Acronictinae). Zootaxa 2678: 48-68.

Hartig, F. (1968): Einige neue Lepidopterenrassen und -formen und eine wiederentdeckte Noctuide aus Süditalien. Reichenbachia 12(1): 1-13.

Heuertz, M., Fineschi, S., Anzidei, M., Pastorelli, R., Salvini, D., Paule, L., FrascariaLacoste, N., Hardy, O. J., Vekemans, X. \& Vendramin, G. G. (2004): Chloroplast DNA variation and postglacial recolonization of common ash (Fraxinus excelsior L.) in Europe. Molecular Ecology 13: 3437-3452. https://doi.org/10.1111/j.1365294X.2004.02333.x

Hewitt, G. M. (1996): Some genetic consequences of ice ages, and their role, in divergence and speciation. Biological Journal of the Linnean Society 58: 247-276. https://doi. org/10.1006/bijl.1996.0035

Hewitt, G. M. (1999): Post-glacial re-colonization of European biota. Biological Journal of the Linnean Society 68: 87-112. https://doi.org/10.1111/j.1095-8312.1999.tb01160.x

Hewitt, G. M. (2004): Genetic consequences of climatic oscillations in the Quaternary. Philosophical Transaction of the Royal Society B 359: 183-195. https://doi.org/10.1098/ rstb.2003.1388

Hinsinger, D. D., Basak, J., Gaudeul, M., Cruaud, C., Bertolino, P., Frascaria-Lacoste, N. \& Bousquet, J. (2013): The Phylogeny and biogeographic history of ashes (Fraxinus, Oleaceae): highlight the roles of migration and vicariance in the diversification of temperate trees. PLOS ONE 8(11): e80431. https://doi.org/10.1371/journal. pone.0080431

Holloway, J. D. (1989): The Moths of Borneo. Part 12 - Family Noctuidae, Trifine Subfamilies: Noctuinae, Heliothinae, Hadeninae, Acronictinae, Amphipyrinae, Agaristinae. Southdene Sdn. Bhd., Kuala Lumpur, 226 pp.

Inoue, H. \& Sugi, S. (1958): Checklist of the Lepidoptera of Japan. Noctuidae. Vol. 5. Rikusuisha, Tokyo, pp. 431-619.

Kiss, Á. \& Gyulai, P. (2013): Two new species and one subspecies of Craniophora Snellen, 1867 (Lepidoptera, Noctuidae, Acronictinae) from China. ZooKeys 353: 61-70. https:// doi.org/10.3897/zookeys.353.5990 
Kononenko, V. S. (2005): An annotated Check list of the Noctuidae (s.l.) (Lepidoptera, Noctuoidea: Nolidae, Erebidae, Micronoctuidae, Noctuidae) of the Asian part of Russia and the Ural region. Noctuidae Sibiricae. Vol. 1. Entomological Press, Sorø, 243 pp.

Kononenko, V. S. (2010): Micronoctuidae, Noctuidae: Rivulinae - Agaristinae (Lepidoptera). Noctuidae Sibiricae. Vol. 2. Entomological Press, Sorø, 475 pp.

Kononenko, V. S., Ahn, S. B. \& Ronkay, L. (1998): Illustrated Catalogue of Noctuidae in Korea, (Lepidoptera). Insects of Korea, Series 3. Junghaeng-Sa, Seul, 507 pp.

Kotlík, P., Deffontaine, V., Mascheretti, S., Zima, J., Michaux, J. R. \& Searle, J. B. (2006): A Northern glacial refugium for bank voles (Chlethrionomys glareolus). Proceedings of the National Academy of Sciences of the United States of America 103(40): 14860-14864. https://doi.org/10.1073/pnas.0603237103

Kozhantshikov, I. V. (1950): Lepidoptera, Orgyiidae, Fauna SSSR. Publishing House of the Academy of Sciences of SSSR, Moscow-Leningrad, 581 pp. [in Russian]

Kravchenko, V. D., Orlova, O., Fibiger, M., Mooser, J., Li, C. \& Müller, G. C. (2006): The Acronictinae, Bryophilinae, Hypenodinae and Hypeninae of Israel (Lepidoptera: Noctuidae). SHILAP Revista de Lepidoterología 34(135): 255-264.

de Lattin, G. (1949): Neue Acronicten II. Zeitschrift der Wiener Entomologischen Gesellschaft 34: 105-112.

Lödl, M., GaAl-Haszler, S., Jovanovic-Kruspel, S., Ronkay, G., Ronkay, L. \& Varga, Z. (2012): The Vartian Collection. Part I. Noctuoidea - Fibigeriana 1. Heterocera Press, Budapest, 303 pp.

Mega, N. O. (2014): The adult body size variation of Dryas iulia (Lepidoptera, Nymphalidae, Heliconiinae) in different populations is more influenced by temperature variation than by host-plant availability during the seasons. Entomological Science 17: 376-387. https://doi.org/10.1111/ens.12077

Mitchell, A., Mitter, Ch. \& Regier, J. C. (2006): Systematics and evolution of the cutworm moths (Lepidoptera: Noctuidae): evidence from two protein-coding nuclear genes. Systematic Entomology 31: 21-46. https://doi.org/10.1111/j.1365-3113.2005.00306.x

Mutanen, M. (2005): Delimitation difficulties in species splits: a morphometric case study on the Euxoa tritici complex (Lepidoptera, Noctuidae). Systematic Entomology 30: 632-643. https://doi.org/10.1111/j.1365-3113.2005.00296.x

Mutanen, M., RYtkönen, S., Lindén, J. \& SinkKonen, J. (2007): Male genital variation in a moth Pammene luedersiana (Lepidoptera: Tortricidae). European Journal of Entomology 104(2): 259-265. https://doi.org/10.14411/eje.2007.040

van Nieukerken, E. J., Kaila, L., Kitching, I. J., Kristensen, N. P., Lees, D. C., Minet, J., Mitter, C., Mutanen, M., Regier, J. C., Simonsen, T. J., Wahlberg, N., Yen, S-H., Zahiri, R., Adamski, D., Baixeras, J., Bartsch, D., Bengtsson, B. Å., Brown, J. W., Bucheli, S. R., Davis, D. R., De Prins, J., De Prins, W., Epstein, M. E., Gentili-Poole, P., Gielis, C., Hättenschwiler, P., Hausmann, A., Holloway, J. D., Kallies, A., Karsholt, O., Kawahara, A. Y., Koster, S. (J. C.), Kozlov, M. V., Lafontaine, J. D., Lamas, G., Landry, J-F., Lee, S., Nuss, M., Park, K-T., Penz, C., Rota, J., Schintlmeister, A., Schmidt, B. C., Sohn, J-C., Solis, M. A., Tarmann, G. M., Warren, A. D., Weller, S., Yakovlev, R. V., Zolotuhin, V. V. \& Zwick, A. (2011): Order Lepidoptera Linnaeus, 1758. Pp. 212-221. In: Zhang, Z.-Q. (ed.): Animal biodiversity: An outline of higher-level classification and survey of taxonomic richness. Zootaxa 3148. https://doi.org/10.11646/ zootaxa.3703.1.1

Poole, R. W. (1989): Noctuidae, Part 1. Lepidopterorum Catalogus (New Series). Fascicle 118. E. J. Brill, Leiden-New York, 500 pp. 
QGIS Development Team (2014): QGIS Geographic Information System. Open Source Geospatial Foundation Project. http://qgis.osgeo.org

R Core Team (2014): R: A language and environment for statistical computing. R Foundation for Statistical Computing, Vienna, Austria. http://www.R-project.org/

Robinson, G. S. (1976): The preparation of slides of Lepidoptera genitalia with special reference to the Microlepidoptera. Entomologist's Gazette 27: 127-132.

RohlF, F. J. (2010): tpsDig, digitize landmarks and outlines, version 2.16. Department of Ecology and Evolution, State University of New York at Stony Brook. Available at http://life. bio.sunysb.edu/morph/

Rohlf, F. J. \& Marcus, L. F. (1993): A revolution in morphometrics. Trends in Ecology $\mathcal{E}$ Evolution 8(4): 129-132. https://doi.org/10.1016/0169-5347(93)90024-J

Ronkay, G., Ronkay, L. \& Gyulai, P. (2011): Cucullinae II and Psaphidinae. A taxonomic atlas of the Eurasian and North African Noctuoidea. Vol. 5. Heterocera Press, Budapest, 380 pp.

Ronkay, L., Yela, J. L. \& Hreblay, M. (2001): Hadeninae II. Noctuidae Europaeae. Vol. 5. Entomological Press, Sorø, 452 pp.

Roskam, J. C. \& Brakefield, P. M. (1999): Seasonal polyphenism in Bicyclus (Lepidoptera: Satyridae) butterflies: different climates need different cues. Biological Journal of the Linnean Society 66: 345-356. https://doi.org/10.1111/j.1095-8312.1999.tb01895.x

Sanzana, M-J., Parra, L. E., Sepúlveda-Zúñiga, E. \& Benítez, H. A. (2013): Latitudinal gradient effect on the wing geometry of Auca coctei (Guérin) (Lepidoptera, Nymphalidae). Revista Brasileira de Entomologia 57(4): 411-416. https://doi.org/10.1590/ S0085-56262013005000045

Schintlmeister, A. (1989): Zoogeographie der palaearktischen Notodontidae (Lepidoptera). Neue Entomologische Nachrichten 25: 1-117.

Schintlmeister, A. \& FAnG, C. L. (2001): New and less known Notodontidae from mainland China (Insecta, Lepidoptera, Notodontidae). Neue Entomologische Nachrichten 50: $1-141$.

Sснмітт, T. (2007): Molecular biogeography of Europe: Pleistocene cycles and postglacial trends. Frontiers in Zoology 4: 1-11. https://doi.org/10.1186/1742-9994-4-11

Sснмitт, T. \& VARgA, Z. (2009): Biogeography of the butterflies and larger moths of the Carpathian Basin and the Balkan Peninsula. Pp. 143-166. In: Stloukal, E., Hensel, K., Holec, P., Illyová, M., Jandzík, D., JedličKa, L., Joniak, P., Juráni, B., Kocian, L., Košel, V., Krno, I., Kúdela, M., Miklós, P., Mikulíček, P., Овuch, J., Schmitt, T., Stankoviansky, M., Stloukalová, V., Varga, Z. S., \& Žıak, D. (eds): Vývoj prírody Slovenska. Faunima, Bratislava.

Schmitt, T. \& VARgA, Z. (2012): Extra-Mediterranean refugia: The rule and not the exception? Frontiers in Zoology 9: 1-22. https://doi.org/10.1186/1742-9994-9-22

Shapiro, A. M. (1974): Natural and laboratory occurrence of "elymi" phenotypes in Cynthia cardui (Nymphalidae). Journal of Research on the Lepidoptera 13(1): 57-62.

Shapiro, A. M. \& Porter, A. H. (1989): The lock-and-key hypothesis: evolutionary and biosystematic interpretation of insect genitalia. Annual Review of Entomology 34: 231-245. https://doi.org/10.1146/annurev.en.34.010189.001311

Stewart, J. R. \& Lister, A. M. (2001): Cryptic Northern refugia and the origins of the modern biota. TRENDS in Ecology and Evolution 16(11): 608-613. https://doi.org/10.1016/ S0169-5347(01)02338-2

Stewart, J. R., Lister, A. M., Barnes, I. \& Dalén, L. (2010): Refugia revisited: individualistic responses of species in space and time. Proceedings of the Royal Society B 277: 661-671. https://doi.org/10.1098/rspb.2009.1272 
Surget-Groba, Y., Heulin, B., Guillaume, C-P., Thorpe, R. S., Kupriyanova, L., Vogrin, N., Maslak, R., Mazzotti, S., Venczel, M., Ghira, I., Odierna, G., Leontyeva, O., Monney, J. C. \& Sмith, N. (2001): Intraspecific phylogeography of Lacerta vivipara and the evolution of viviparity. Molecular Phylogenetics and Evolution 18(3): 449-459. https://doi.org/10.1006/mpev.2000.0896

Suzuki, R. \& SHimodaira, H. (2011): pvclust: Hierarchical clustering with p-values via multiscale bootstrap resampling. R package version 1.2-2. http://CRAN.R-project.org/ package $=$ pvclust

Taberlet, P., Fumagalli, L., Wust-Saucy, A-G. \& Cosson, J-F. (1998): Comparative phylogeography and postglacial colonization routes in Europe. Molecular Ecology 7: 453464. https://doi.org/10.1046/j.1365-294x.1998.00289.x

Tóth, J. P. \& VARgA, Z. (2010): Morphometric study on the genitalia of sibling species Melitaea phoebe and M. telona (Lepidoptera: Nymphalidae). Acta Zoologica Academiae Scientiarum Hungaricae 56(3): 273-282.

Tóth, J. P. \& VARGA, Z. (2011): Inter- and intraspecific variation in the genitalia of the 'Melitaea phoebe group' (Lepidoptera, Nymphalidae). Zoologischer Anzeiger 250: 258-268. https://doi.org/10.1016/j.jcz.2011.05.002

Tóth, J. P., Bereczki, J., Varga, Z., Rota, J., Sramkó, G. \& Wahlberg, N. (2014): Relationships within the Melitaea phoebe species group (Lepidoptera: Nymphalidae): new insights from molecular and morphometric information. Systematic Entomology 39: 749-757. https://doi.org/10.1111/syen.12083

Ursenbacher, S., Carlsson, M., Helfer, V., Tegelström, H. \& Fumagalli, L. (2006): Phylogeography and Pleistocene refugia of the adder (Vipera berus) as inferred from mitochondrial DNA sequence data. Molecular Ecology 15: 3425-3437. https://doi. org/10.1111/j.1365-294X.2006.03031.x

VARGA, Z. (2010): Extra-Mediterranean refugia, post-glacial vegetation history and area dynamics in Eastern Central Europe. Pp. 57-87. In: Habel, J. C. \& Assmann, T. (eds): Relict species: phylogeography and conservation biology. Springer-Verlag, Berlin, Heidelberg. https://doi.org/10.1007/978-3-540-92160-8_3

Wahlberg, N., Wheat, C. W. \& PeÑA, C. (2013): Timing and patterns in the taxonomic diversification of Lepidoptera (butterflies and moths). PLoS ONE 8(11): e80875. https:// doi.org/10.1371/journal.pone.0080875

Wallander, E. (2008): Systematics of Fraxinus (Oleaceae) and evolution of dioecy. Plant Systematics and Evolution 273: 25-49. https://doi.org/10.1007/s00606-008-0005-3

Zahiri, R., Kitching, I. J., Lafontaine, J. D., Mutanen, M., Kaila, L., Holloway, J. D. \& WAHLBERG, N. (2011): A new molecular phylogeny offers hope for a stable family level classification of the Noctuoidea (Lepidoptera). Zoologica Scripta 40(2): 158-173. https://doi.org/10.1111/j.1463-6409.2010.00459.x

Zelditch, M. L., Swiderski, D. L., Sheets, H. D. \& Fink, W. L. (2004): Geometric morphometrics for biologists: A primer. Elsevier Academic Press, New York and London, 437 pp.

Zilli, A., Varga, Z., Ronkay, G. \& Ronkay, L. (2009): Apameini I. A taxonomic atlas of the Eurasian and North African Noctuoidea. Vol. 3. Heterocera Press, Budapest, 393 pp.

Received May 22, 2015, accepted December 7, 2015, published March 3, 2017 


\section{SYNTHESYS I}

\section{Synthesis of systematic resources}
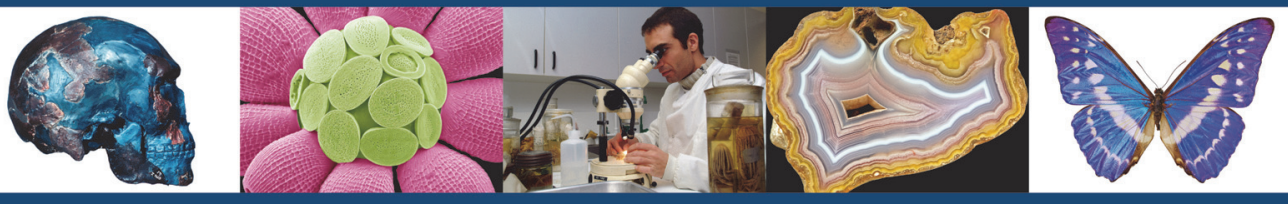

\section{Access to research infrastructures}

SYNTHESYS offers unique research opportunities to scientists from all over Europe. Access is provided to:

- European collections comprising more than half of the world's natural history specimens

- world class libraries

- state-of-the-art facilities including imaging, chemical, and molecular laboratories

- support from in-house scientists, including researchers, facilities staff, and collections managers

Participation is free of charge and is provided on the basis of scientific excellence of a proposal, reviewed by a Selection Panel. Priority is given to new users. A typical project is 1-6 weeks in duration.

The 18 partner institutions offer access via 11 national Taxonomic Access Facilities (TAFs).

\begin{tabular}{|c|c|c|c|}
\hline AT-TAF: & Naturhistorisches Museum, Vienna & DK-TAF: & University of Copenhagen \\
\hline \multirow[t]{2}{*}{ BE-TAF: } & $\begin{array}{l}\text { Royal Belgian Institute of Natural } \\
\text { Sciences, Brussels; Royal Museum for }\end{array}$ & ES-TAF: & $\begin{array}{l}\text { Museo Nacional de Ciencias Naturales } \\
\text { \& Real Jardín Botánico, Madrid }\end{array}$ \\
\hline & Central Africa, Tervuren & FR-TAF: & Muséum National d'Histoire Naturelle, \\
\hline CZ-TAF: & Národní Muzeum, Prague & & Paris \\
\hline \multirow[t]{4}{*}{ DE-TAF: } & $\begin{array}{l}\text { Botanischer Garten und Botanisches } \\
\text { Museum Berlin-Dahlem, Berlin; } \\
\text { Museum für Naturkunde, Berlin; }\end{array}$ & GB-TAF: & $\begin{array}{l}\text { Natural History Museum, London; } \\
\text { Royal Botanic Gardens, Kew; } \\
\text { Royal Botanic Garden, Edinburgh }\end{array}$ \\
\hline & $\begin{array}{l}\text { Senckenberg Gesellschaft für } \\
\text { Naturforschung, Frankfurt, Dresden, }\end{array}$ & HU-TAF: & $\begin{array}{l}\text { Hungarian Natural History Museum, } \\
\text { Budapest }\end{array}$ \\
\hline & Görlitz and Müncheberg; Staatliches & NL-TAF: & Naturalis Biodiversity Center, Leiden \\
\hline & Museum für Naturkunde, Stuttgart & SE-TAF: & Naturhistoriska riksmuseet, Stockholm \\
\hline
\end{tabular}

SYNTHESYS will provide finance for:
research costs
uper diem contribution towards living costs
口 international travel and accommodation
- logistical support at the host institution

Contact SYNTHESYS for details of the online application process and deadlines: Annual Calls for proposals in October (2013 - 2016)

Visits will be scheduled between January 2014 and August 2017 email: synthesys@nhm.ac.uk

www.synthesys.info

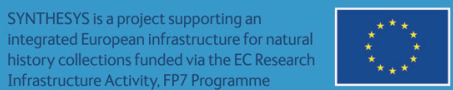

